\title{
The adaptor protein Disabled-2: new insights into platelet biology and integrin signaling
}

Hui-Ju Tsai ${ }^{1,2}$ and Ching-Ping Tseng ${ }^{1,2,3,4^{*}}$

From The 9th Congress of the Asian-Pacific Society on Thrombosis and Hemostasis

Taipei, Taiwan. 6-9 October 2016

\begin{abstract}
Multiple functions of platelets in various physiological and pathological conditions have prompted considerable attention on understanding how platelets are generated and activated. Of the adaptor proteins that are expressed in megakaryocytes and platelets, Disabled-2 (Dab2) has been demonstrated in the past decades as a key regulator of platelet signaling. Dab2 has two alternative splicing isoforms p82 and p59. However, the mode of Dab2's action remains to be clearly defined. In this review, we highlight the current understanding of Dab2 expression and function in megakaryocytic differentiation, platelet activation and integrin signaling. Accordingly, Dab2 is upregulated when the human $\mathrm{K} 562$ cells, human CD34 ${ }^{+}$hematopoietic stem cells, and murine embryonic stem cells were undergone megakaryocytic differentiation. Appropriate level of Dab2 expression is essential for fate determination of mesodermal and megakaryocytic differentiation. Dab2 is also shown to regulate cell-cell and cell-fibrinogen adhesion, integrin allbß33 activation, fibrinogen uptake, and intracellular signaling of the megakaryocytic cells. In human platelets, p82 is the sole Dab2 isoform present in the cytoplasm and a-granules. Dab2 is released from the a-granules and forms two pools of Dab2 on the outer surface of the platelet plasma membrane, one at the sulfatide-bound and the other at integrin allb $\beta 3$-bound forms. The balance between these two pools of Dab2 controls the extent of clotting reaction, platelet-fibrinogen interactions and outside-in signaling. In murine platelets, p59 is the only Dab2 isoform and is required for platelet aggregation, fibrinogen uptake, RhoA-ROCK activation, adenosine diphosphate release and integrin allb $\beta 3$ activation stimulated by low concentration of thrombin. As a result, the bleeding time is prolonged and thrombus formation is impaired for the megakaryocyte lineage-restricted Dab2 deficient mouse. Although discrepancies of Dab2 function and isoform expression are noted between human and murine platelets, the studies up-to-date define Dab2 playing a pivotal role in integrin signaling and platelet activation. With the new tools such as CRISPR and TALEN in the generation of genetically modified animals, the progress in gaining new insights into the functions of Dab2 in megakaryocyte and platelet biology is expected to accelerate.
\end{abstract}

Keywords: Disabled-2, Integrin allbß3, Megakaryocyte, Platelet

(Continued on next page)

\footnotetext{
* Correspondence: ctseng@mail.cgu.edu.tw

${ }^{1}$ Department of Medical Biotechnology and Laboratory Science, Collage of

Medicine, Chang Gung University, Kweishan, Taoyuan 333, Taiwan, Republic

of China

${ }^{2}$ Molecular Medicine Research Center, Chang Gung University, Kweishan,

Taoyuan 333, Taiwan, Republic of China

Full list of author information is available at the end of the article
} 
(Continued from previous page)

Abbreviations: ADP, Adenosine diphosphate; CSF-1, Colony-stimulating factor-1; Dab2, Disabled-2; ESCs, Embryonic stem cells; ITAM, Immunoreceptor tyrosine-based activation motif; PARs, Protease-activated receptors; PKC, Protein kinase C; PRD, Proline rich domain; PTB, Phosphotyrosine binding domain; TPA, 12-O-tetradecanoylphorbol-13-acetate; $\mathrm{TXA}_{2}$, Thromboxane $\mathrm{A}_{2}$

\section{Background}

Platelets are the second most abundant blood cells and are derived from the cytoplasm of megakaryocytes [1]. The crucial role of platelet in haemostasis and thrombosis has prompted extensive attentions on unveiling the underlying mechanisms of platelet activation induced by soluble agonists [2-4]. Platelet activation is mainly mediated by binding of ligands to the membrane receptors such as the immunoglobulin family of glycoproteins for collagen and the G-protein coupled receptors for thrombin, thromboxane A2 $\left(\mathrm{TXA}_{2}\right)$ and adenosine diphosphate (ADP) [5]. Collagen interacts with glycoprotein VI which contains an immunoreceptor tyrosine-based activation motif (ITAM). The ITAM is phosphoryated by two Src kinases (Lyn and Fyn) and recruits the protein tyrosine kinase Syk to the plasma membrane for phosphorylation of downstream substrates at the tyrosine residue that are essential for platelet activation [5]. Other soluble agonists such as thrombin, $\mathrm{TXA}_{2}$ and ADP bind to the respective G protein-coupled receptors and cause an increase in intracellular calcium and protein kinase C (PKC) activity, Rho activation, inhibition of adenylyl cyclase and activation of phosphoinositide 3-kinase-Akt through the $\mathrm{G \alpha}_{\mathrm{q}^{-}}, \mathrm{G \alpha}_{12 / 13^{-}}$, $\mathrm{G \alpha}_{\mathrm{i}^{-}}$, and $\mathrm{G} \beta \gamma$-dependent pathway, respectively $[5,6]$. The inside-out signaling induced by different platelet agonists activates integrin $\alpha \operatorname{IIb} \beta 3$ followed by the binding of fibrinogen to integrin $\alpha \operatorname{IIb} \beta 3$ and activation of outside-in signaling. These intracellular events ultimately lead to platelet activation, secretion and aggregation [7]. Despite extensive studies, the underlying mechanisms of platelet signaling networks still wait to be fully elucidated.

Adaptor protein is a type of proteins mediating proteinprotein and protein-lipid interactions. It has been clearly demonstrated that adaptor proteins are essential for coupling membrane receptors to intracellular signaling pathways and the assembly of signaling scaffolds within the cells. Many adaptor proteins expressed in the platelets are involved in inside-out and outside-in signaling of integrin during platelet activation [8]. Disabled-2 (Dab2) is a newly identified adaptor protein that is known to express in megakaryocytes and platelets from a variety of species $[9,10]$. The current knowledge about the roles of Dab2 in megakaryocytic differentiation and platelet signaling is still in the beginning. This review will focus on the expression and functional aspects of Dab2 in megakaryocytic differentiation, platelet activation and integrin signaling.

\section{Review}

Discovery and the protein properties of Dab2

Human dab2 gene is located at the chromosome 5p13 and was first identified by Mok et al. as the tumor suppressor gene of the ovary cancer in 1994 [11]. The mouse Dab2 protein was then revealed in 1995 during the analysis of phosphoproteins induced by colony-stimulating factor-1 (CSF-1) in macrophage [12]. In 1998, Tseng et al. further defined rat dab2 as the differentially expressed gene that was up-regulated in the castrated rat prostate [13]. At least two Dab2 isoforms with the molecular weight of 82 and $59 \mathrm{kDa}$, referred to p82-Dab2 and p59-Dab2, respectively, are generated through alternative splicing (Fig. 1) [14]. Because of the undefined posttranslational protein modification, the protein bands of p82-Dab2 and p59-Dab2 are up-shifted to the positions at 96 and $67 \mathrm{kDa}$ on sodium dodecyl sulfate-polyacrylamide gel electrophoresis. Hence, p82-Dab2 and p59-Dab2 sometimes are referred to p96-Dab2 and p67-Dab2, respectively. The ninth coding exon corresponding to the amino acids 230-447 of p82-Dab2 is not present in the protein of p59-Dab2. As a result, several binding sites for endocytic proteins are absent in p59-Dab2. Particular motifs mediating protein-protein and protein-lipid interactions are present in Dab2, allowing them to communicate with other signaling molecules. The phosphotyrosine binding (PTB) domain is located at the N-terminus of Dab2, playing a role in the interaction of Dab2 with DIP1/2, Smad2/3, Dishevelled-3, phosphatidylinositol 4,5-bisphosphate $\left(\mathrm{PI}(4,5) \mathrm{P}_{2}\right)$, and a subset of receptors such as integrin, low density lipoprotein receptor, megalin and related receptors that contain the non-tyrosinephosphorylated NPXY motif [14-21]. The aspartic acidproline-phenylalanine (DPF) motif of Dab2 interacts with the $\alpha$-adaptin subunit of the clathrin adaptor protein 2 (AP-2) [21]. The C-terminal proline-rich domain (PRD) interacts with Grb2, c-Src, Akt and c-Cbl-interacting protein of $85 \mathrm{kDa}$ [22-26]. By interacting with other cellular factors through these motifs, Dab2 elicits its functions in endocytosis, differentiation, and immune response and is involved in the cell signaling pathways of Ras-mitogen activated protein kinase (MAPK), Wnt, TGF- $\beta$, c-Src and RhoA-ROCK [24, 27-36]. Dab2 is also known to regulate cytoskeleton reorganization by binding to nonmuscle myosin heavy chain IIA, myosin VI, actin, and dynein [12, 37-39]. 


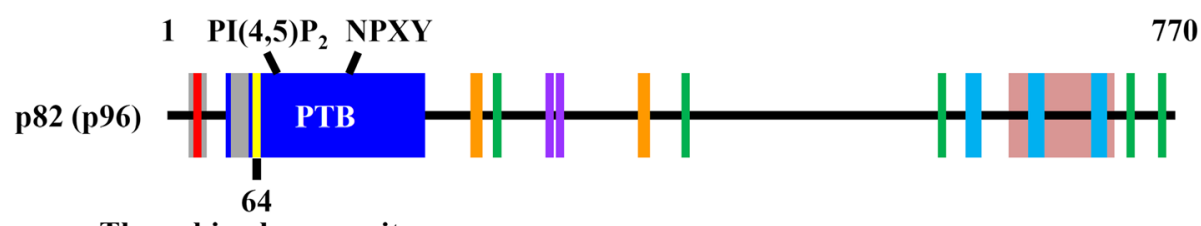

Thrombin cleavage site

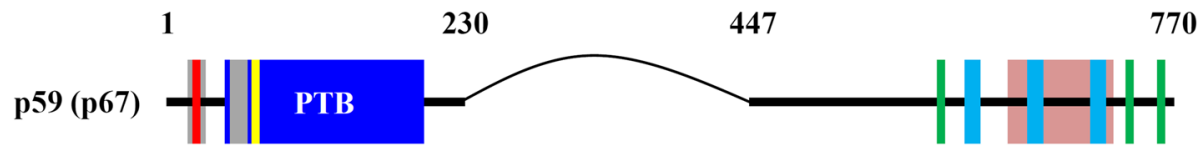

Actin-binding motif
Sulfatide binding site
RGD motif
Clathrin Type I/II box

Aspartic acid-proline-phenylalanine (DPF) motif

Asparagine-proline-phenylalanine (NPF) motif

Proline-rich domain (PRD)

Myosin VI binding domain

Fig. 1 Schematic illustration for the primary protein structure of Dab2. The primary structures for both Dab2 isoforms p82 (p96) and p59 (p67) are shown. The p59 (p67) isoform of Dab2 lacks the ninth coding exon corresponding to the amino acid residues of 230-447 and results in the deletion of several binding sites for endocytic proteins. The $\mathrm{N}$-terminus of Dab2 contains an actin-binding motif ${ }^{25} \mathrm{KKEK}{ }^{28}$ ), two sulfatide binding sites (amino acid residues 24-32 and 49-54), an RGD motif $\left({ }^{64} R G D{ }^{66}\right)$, one thrombin cleavage site $\left({ }^{64} \mathrm{R}\right)$ and the PTB domain (amino acid residues 45-196). Dab2-PTB is the binding sites for $\mathrm{PI}(4,5) \mathrm{P}_{2}$ and the tails of a subset of non-tyrosine-phosphorylated NPXY-containing receptors. The clathrin type I $\left.{ }^{236} \mathrm{LVDLN}^{240}\right)$ and type II ( ${ }^{363}$ PWPFS $\left.^{367}\right)$ box sequences, and the two DPF motifs $\left({ }^{293}\right.$ DPFRDDPF $\left.^{300}\right)$ are located at the middle region of Dab2 protein. The DPF motifs bind to the a-adaptin subunit of the clathrin adaptor protein AP-2. The five asparagine-proline-phenylalanine (NPF) motifs spanning the middle and Cterminus of Dab2 possibly bind proteins containing Eps homology domain. The C-terminus of Dab2 contains the myosin VI binding domain and the PRD for the binding of proteins containing SH3 domain

Dab2 is a phosphoprotein with several phosphoryation sites having been identified. Dab2 is phosphorylated at serine residues in murine macrophage cell line in response to mitogenic stimulation by CSF-1 [12]. Dab2Ser24 is phosphorylated by PKC $\beta I I, \gamma$ and $\delta$ but not by casein kinase II, playing a critical role in the inhibition of 12-O-tetradecanoylphorbol-13-acetate (TPA)-induced AP-1 activity and integrin activation [33, 40]. Dab2 is hyperphosphorylated by the cyclin-dependent serine/ threonine kinase $\mathrm{Cdc} 2$ during the mitosis phase of the cell cycle in HeLa S3 cells [41]. The phosphorylated Dab2 interacts with the peptidylprolyl isomerase Pin1 that facilitates Dab2 dephosphorylation immediately after the end of mitosis phase [42]. Similarly, Akt interacts with PRD domain of Dab2 and phosphorylates Ser448/Ser449 to regulate albumin endocytosis and mediate albumin uptake in proximal tubule $[25,43]$. These distinct protein properties facilitate the involvement of Dab2 in diverse signaling network in response to extracellular responses.

\section{Expression pattern of Dab2 in megakaryocytes and platelets}

The first study addressing Dab2 expression and function in megakaryocytes and platelets was published in 2001 [31]. Dab2 is upregulated when the human leukemic K562 cells, human $\mathrm{CD}^{+}{ }^{+}$hematopoietic pluripotent stem cells, and murine embryonic stem cells (ESCs) are undergone megakaryocytic differentiation (Table 1) [31-33, 35]. Among the platelets from the species of murine, rat, and human, murine platelets have the least amount of Dab2 [9]. This is in accord with the genome-wide RNA-seq analysis of platelet transcriptomes that revealed several thousands-fold differences for the expression of Dab2 transcripts between human and mouse platelets [44]. Moreover, Dab2 isoforms are differentially expressed in human, rat and murine platelets. Both p82-Dab2 and p59Dab2 are detectable in the rat platelets, while p82-Dab2 and p59-Dab2 is mainly expressed in the platelets from human and murine, respectively [9].

The evolutionary roles for an increase in Dab2 expression from mouse to rat and human platelets and the species-specific expression of Dab2 isoforms are not yet understood. Distinctive functions of p82-Dab2 and p59Dab2 have been unveiled in several studies. p82-Dab2 is known to regulate receptor-mediated endocytosis, while p59-Dab2 is a transcriptional regulator when the F9 cells are undergone differentiation $[18,20,45,46]$. Knock-in expression of p59-Dab2 only partially compromises the absence of Dab2 in the Dab2-knockout mice [14]. The increased expression of $\mathrm{p} 82-\mathrm{Dab} 2$ protein in human platelets may fine tune platelet response to soluble agonists and provide a superior way to prevent excessive blood loss in the large mammals. Future study using an in vivo animal model expressing human platelet p82-Dab2 should provide new insight for the aforementioned hypothesis. 
Table 1 Dab2 expression and function in megakaryocytes and platelets

\begin{tabular}{|c|c|c|}
\hline Experimental systems & Reported Dab2 expression/function & References \\
\hline \multirow[t]{3}{*}{ Human K562 cells } & $\begin{array}{l}\text { Increased Dab2 expression } \\
\text { during TPA-induced } \\
\text { megakaryocytic differentiation }\end{array}$ & \multirow[t]{3}{*}[19,31-34]{} \\
\hline & $\begin{array}{l}\text { Positive regulation of fibrinogen } \\
\text { uptake }\end{array}$ & \\
\hline & $\begin{array}{l}\text { Dab2 interacts with integrin } \beta 3 \\
\text { and inhibits integrin allb } \beta 3 \\
\text { activation }\end{array}$ & \\
\hline $\begin{array}{l}\text { Human CD } 34^{+} \\
\text {stem cells }\end{array}$ & $\begin{array}{l}\text { Increased Dab2 expression during } \\
\text { TPO-induced megakaryocytic } \\
\text { differentiation }\end{array}$ & [10] \\
\hline \multirow[t]{2}{*}{$\begin{array}{l}\text { Mouse embryonic } \\
\text { stem cells/OP9 } \\
\text { co-culture }\end{array}$} & $\begin{array}{l}\text { Increased Dab2 expression during } \\
\text { mesodermal and megakaryocytic } \\
\text { differentiation }\end{array}$ & \multirow[t]{2}{*}[35]{} \\
\hline & $\begin{array}{l}\text { Dab2 is required for mesodermal } \\
\text { differentiation }\end{array}$ & \\
\hline \multirow[t]{4}{*}{ Human platelets } & $\begin{array}{l}\text { High expression of p82-Dab2 in } \\
\text { the cytoplasm and a-granule }\end{array}$ & \multirow[t]{4}{*}{$\begin{array}{l}{[10,33} \\
47-49]\end{array}$} \\
\hline & $\begin{array}{l}\text { Dab2 interacts with the cytoplamic } \\
\text { tail of platelet integrin }\end{array}$ & \\
\hline & $\begin{array}{l}\text { Secreted Dab2 interacts with } \\
\text { integrin allb and sulfatide; is } \\
\text { a substrate of thrombin }\end{array}$ & \\
\hline & $\begin{array}{l}\text { Dab2 regulates fibrinogen binding } \\
\text { and homotypic and heterotypic } \\
\text { platelet interactions }\end{array}$ & \\
\hline \multirow[t]{3}{*}{ Mouse platelets } & Low expression of p59-Dab2 & \multirow[t]{3}{*}{ [9] } \\
\hline & $\begin{array}{l}\text { Dab2-deficient mice display a } \\
\text { prolonged bleeding time and } \\
\text { impaired thrombus formation }\end{array}$ & \\
\hline & $\begin{array}{l}\text { Dab2 is required for platelet } \\
\text { aggregation, fibrinogen } \\
\text { uptake, RhoA-ROCK activation, } \\
\text { ADP release and integrin allb } \beta 3 \\
\text { activation stimulated by low } \\
\text { concentration of thrombin }\end{array}$ & \\
\hline
\end{tabular}

\section{Dab2 functions in megakaryocytic differentiation and platelet signaling}

Dab2 has been shown to elicit multiple functions in megakaryocytic differentiation and platelet signaling (Table 1 and Fig. 2). The human K562 leukemic cells induced by TPA to form megakaryocyte-like cells have been used to define the role of Dab2 in integrin activation, cell adhesion, fibrinogen uptake, and megakaryocytic differentiation [31-34]. Dab2 is crucial in cell-cell adhesion of K562 cells and negatively regulates integrin $\alpha \mathrm{IIb} \beta 3$ activation and cell adhesion to fibrinogen. A mutual regulation between Dab2 and MAPK was also unveiled when the K562 cells are undergone megakaryocytic differentiation $[31,32]$. Dab2 colocalizes with clathrin and mediates fibrinogen uptake in the primary megakaryocytes and megakaryocytic differentiating K562 cells [34]. Dab2- associated regulatory circuit controls mesoderm and megakaryocytic differentiation by regulating $\beta$-catenin and plakoglobin cellular distribution through the interaction between the PTB domain of Dab2 and the Asn-ProAsp-Tyr motif of plakoglobin [35]. Accordingly, downregulation of Dab2 in murine ESCs disrupts cell-cell adhesion and affects embryoid body and colony formation leading to impaired mesodermal and megakaryocytic differentiation. Multiple roles of Dab2 in intracellular signaling, integrin activation and fibrinogen uptake of the megakaryocytic cells, and the fate determination of mesodermal and megakaryocytic differentiation were defined by these studies.

Dab2 is present in the cytoplasm and $\alpha$-granules of human platelets and is released from the platelets in response to platelet activation [10]. Dab2 is shown in a number of studies playing a pivotal role in the activation of human platelets. Dab2 interacts with the cytoplasmic tail of the platelet integrin and regulates inside-out signaling [33]. On the other hand, Dab2 released from the $\alpha$-granules is able to bind the extracellular region of $\alpha \operatorname{IIb} \beta 3$ integrin through the Dab2 cell-adhesion ArgGly-Asp (RGD) motif (amino acid residues 64-66) and the fibrinogen binding region of integrin $\alpha$ IIb. Such interactions compete for the integrin $\alpha$ IIb-fibrinogen interactions and inhibit platelet aggregation induced by soluble agonists except thrombin. Thrombin renders Dab2 inactive by cleavage of Dab2 at the amino acid residue 64 [10]. Notably, the action of thrombin on Dab2 cleavage is suppressed when Dab2 binds to the phospholipid sulfatide through four positively charged residues (Lys25, Lys49, Lys51, and Lys53) located at the PTB domain [47]. Hence, two pools of Dab2 is present at the outer surface of the platelet plasma membrane, one at the sulfatide-bound and the other at the integrin $\alpha \operatorname{IIb} \beta 3$-bound states. The balance between these two Dab2 states is involved in the regulation of clotting reaction, platelet aggregation and the interactions of platelet and fibrinogen in response to stimulation by platelet agonists [10, 47-49].

Megakaryocyte/platelet lineage-restricted Dab2 knockout $\left(\mathrm{Dab2} 2^{-/-}\right)$mice have been generated by using the Cre-loxP transgenic system driven by the platelet factor 4 promoter to elucidate Dab2 functions in vivo [9]. $\mathrm{Dab}^{-/-}$platelets, when stimulated by low concentrations of thrombin, are defective in platelet aggregation, clot retraction, and spreading on fibrinogen. The functional imperfection of $\mathrm{Dab}^{-/-}$platelets is related to the defective responses to thrombin-induced RhoA-ROCKII and Akt-mTOR activation, ADP release and integrin $\alpha \operatorname{IIb} \beta 3$ activation [9]. Although Dab2 elicits a restrictive function to the murine platelets stimulated by low concentrations of thrombin, defective Dab2 expression has profound effects on hemostasis and thrombosis in vivo. 


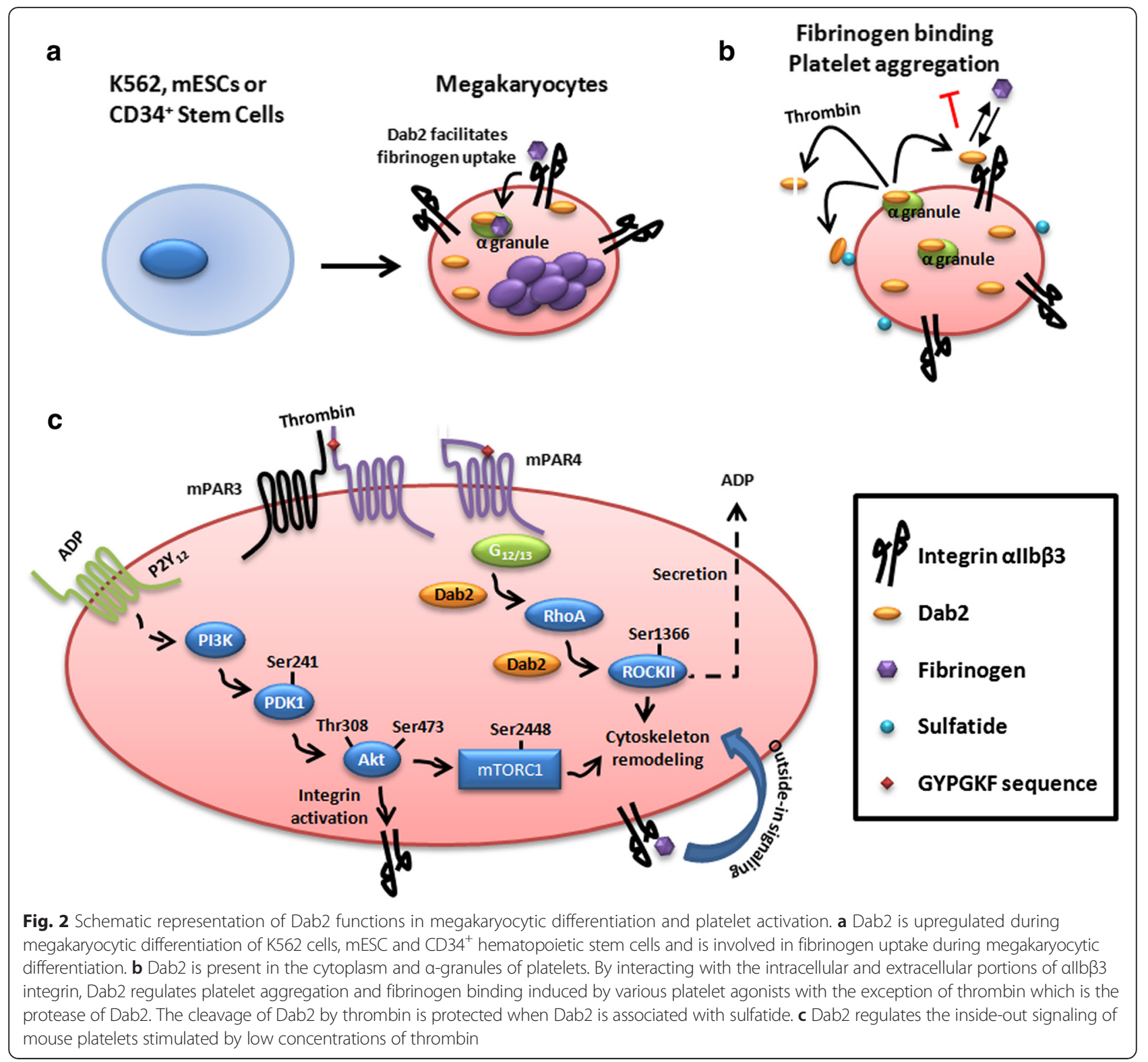

This is evidenced by the observations that bleeding time is prolonged and thrombus formation is impaired in the $\mathrm{Dab}^{-/-}$mice. These findings are consistent with the perception that protease-activated receptors (PAR) 3- and PAR4-deficient mice, despite eliciting a partial decrease in thrombin-induced platelet aggregation, are impaired in hemostasis and are protected against thrombosis $[50,51]$. These studies support the notion that Dab2 is a key regulator in hemostasis and thrombosis.

The consensuses, controversies and future prospects The study linking Dab2 functions with megakaryocytic differentiation, platelet signaling and integrin activation was first reported 15 years ago [31]. The studies up-todate support extensively that Dab2 is a regulator of megakaryocytic differentiation and platelet function. Nevertheless, distinctive functions of Dab2 in human and mouse megakaryocytes and platelets are noted. Knockdown of Dab2 results in an increase in $\alpha \operatorname{IIb} \beta 3$ activation and cell adhesion to fibrinogen in the $\mathrm{K} 562$ cells [33]. Dab2 is, however, required for murine platelet aggregation and integrin $\alpha \operatorname{IIb} \beta 3$ activation when the platelets are stimulated by low concentrations of thrombin [9]. Dab2 negatively regulates human platelet-fibrinogen interaction and platelet aggregation induced by soluble agonists except thrombin [10, 47-49]. The complexity in the abundance and species-specific expression of Dab2 isoforms and the diverse thrombin signaling in human and murine platelets $[6,9]$ likely contribute to the reported heterogeneity of Dab2 function. Alternatively, 
the discrepancy in these findings could be due to the different assay systems being used in these studies. In the studies of human platelets, recombinant Dab2 protein was the main tool for analyzing the effects of Dab2 function on platelet response by in vitro experiments [10, 47-49]. There are no Dab2 mutants or Dab2deficient human platelets available for in vivo study. On the other hand, Dab2-deficient murine platelets have been generated for analysis of Dab2 function in vivo [9]. An animal model expressing human platelet Dab2 should help us to understand the distinctive Dab2 functions in human and murine platelets.

Dab2 is known as a phosphoprotein in a variety of cellular processes $[12,25,33,40-43]$. Due to the lack of appropriate tools, the physiological functions of Dab2 phosphorylation in platelet signaling have not yet been elucidated. We have addressed these issues in our recent work and revealed that Dab2 is phosphorylated during agonist-stimulated human platelet activation (unpublished data). With the new tools such as CRISPR and TALEN [52-55] in the generation of genetically modified animals, the progress in gaining new insights into the signaling network involving Dab2 expression and phosphorylation in megakaryocyte, platelet biology and integrin signaling is expected to accelerate.

\section{Conclusions}

Multiple functions of platelets in hemostasis, thrombosis, immunology, cancer progression, microorganism infections call for considerable attention on understanding how the activated platelets transmit intracellular signal to elicit their roles in different biological responses. Extensive evidence from the studies in the past decades demonstrates that Dab2 is a key regulator of platelet signaling, in particular, the endocytosis and the activation of thrombinstimulated inside-out signaling of platelet integrin. With the complicated nature of the signaling network within megakaryocytes and platelets, the definitive roles of Dab2 in megakaryocytic differentiation, platelet activation and integrin signaling remain to be explored further.

\section{Declaration}

Publication fees for this article have been funded by APSTH 2016.

This article has been published as part of Thrombosis Journal Volume 14 Supplement 1, 2016. The full contents of the supplement are available at https://thrombosisjournal.biomedcentral.com/articles/supplements/volume14-supplement-1

\section{Funding}

The work performed in the authors' laboratory was supported in part by the Ministry of Science and Technology grants MOST102-2628-B-182-009-MY3, MOST102-2628-B-182-010-MY3, MOST105-2320-B-182-029-MY3, MOST105-2320B-182-030, the Chang Gung Memorial Hospital grants (CMRPD1C0551-3, CMRPD1B0391-3, CMRPD1E0181-3, and BMRP466), and the Chang Gung Molecular Medicine Research Center grant (EMRPD1E1491) to C.-P. Tseng; the Ministry of Science and Technology post-doctoral fellowship grants 104-2811-B182-004 and 104-2811-B-182-006 to H.J. Tsai.
Availability of data and materials

Not applicable.

\section{Authors' contributions}

HJT and CPT contributed in the conception and the design of the article and have given final approval of the version to be submitted.

\section{Competing interests}

The authors declare that they have no competing interests.

\section{Consent for publication}

Not applicable.

Ethics approval and consent to participate

Not applicable.

\section{Author details}

'Department of Medical Biotechnology and Laboratory Science, Collage of Medicine, Chang Gung University, Kweishan, Taoyuan 333, Taiwan, Republic of China. ${ }^{2}$ Molecular Medicine Research Center, Chang Gung University, Kweishan, Taoyuan 333, Taiwan, Republic of China. ${ }^{3}$ Graduate Institute of Biomedical Science, Collage of Medicine, Chang Gung University, Kweishan Taoyuan 333, Taiwan, Republic of China. ${ }^{4}$ Department of Laboratory Medicine, Chang Gung Memorial Hospital, Kweishan, Taoyuan 333, Taiwan, Republic of China.

Published: 4 October 2016

\section{References}

1. George JN. Platelets. Lancet. 2000;355:1531-9.

2. Chong AJ, Pohlman TH, Hampton CR, Shimamoto A, Mackman N, Verrier ED. Tissue factor and thrombin mediate myocardial ischemia-reperfusion injury. Ann Thorac Surg. 2003;75:5649-55.

3. Schonberger T, Ziegler M, Borst O, Konrad I, Nieswandt B, Massberg S, Ochmann C, Jurgens T, Seizer P, Langer $H$, et al. The dimeric platelet collagen receptor GPVI-Fc reduces platelet adhesion to activated endothelium and preserves myocardial function after transient ischemia in mice. Am J Physiol Cell Physiol. 2012;303:C757-66.

4. White HD. Oral antiplatelet therapy for atherothrombotic disease: current evidence and new directions. Am Heart J. 2011;161:450-61.

5. Li Z, Delaney MK, O'Brien KA, Du X. Signaling during platelet adhesion and activation. Arterioscler Thromb Vasc Biol. 2010;30:2341-9.

6. Coughlin SR. Thrombin signalling and protease-activated receptors. Nature. 2000;407:258-64.

7. Shen B, Delaney MK, Du X. Inside-out, outside-in, and inside-outside-in: $\mathrm{G}$ protein signaling in integrin-mediated cell adhesion, spreading, and retraction. Curr Opin Cell Biol. 2012;24:600-6.

8. Leo A, Schraven B. Networks in signal transduction: the role of adaptor proteins in platelet activation. Platelets. 2000;11:429-45.

9. Tsai HJ, Huang CL, Chang YW, Huang DY, Lin CC, Cooper JA, Cheng JC, Tseng CP. Disabled-2 is required for efficient hemostasis and platelet activation by thrombin in mice. Arterioscler Thromb Vasc Biol. 2014;34: 2404-12.

10. Huang CL, Cheng JC, Stern A, Hsieh JT, Liao CH, Tseng CP. Disabled-2 is a novel alphallb-integrin-binding protein that negatively regulates plateletfibrinogen interactions and platelet aggregation. J Cell Sci. 2006;119:4420-30.

11. Mok SC, Wong KK, Chan RK, Lau CC, Tsao SW, Knapp RC, Berkowitz RS. Molecular cloning of differentially expressed genes in human epithelial ovarian cancer. Gynecol Oncol. 1994;52:247-52.

12. Xu XX, Yang W, Jackowski S, Rock CO. Cloning of a novel phosphoprotein regulated by colony-stimulating factor 1 shares a domain with the Drosophila disabled gene product. J Biol Chem. 1995;270:14184-91.

13. Tseng $C P$, Ely BD, Li Y, Pong RC, Hsieh JT. Regulation of rat DOC-2 gene during castration-induced rat ventral prostate degeneration and its growth inhibitory function in human prostatic carcinoma cells. Endocrinology. 1998;139:3542-53

14. Maurer ME, Cooper JA. Endocytosis of megalin by visceral endoderm cells requires the Dab2 adaptor protein. J Cell Sci. 2005;118:5345-55.

15. Wang Z, Tseng CP, Pong RC, Chen H, McConnell JD, Navone N, Hsieh JT. The mechanism of growth-inhibitory effect of DOC-2/DAB2 in prostate 
cancer. Characterization of a novel GTPase-activating protein associated with N-terminal domain of DOC-2/DAB2. J Biol Chem. 2002;277:12622-31.

16. Hocevar BA, Smine A, Xu XX, Howe PH. The adaptor molecule Disabled-2 links the transforming growth factor beta receptors to the Smad pathway. EMBO J. 2001;20:2789-801.

17. Hocevar BA, Mou F, Rennolds JL, Morris SM, Cooper JA, Howe PH Regulation of the Wnt signaling pathway by disabled-2 (Dab2). EMBO J. 2003;22:3084-94

18. Mishra SK, Keyel PA, Hawryluk MJ, Agostinelli NR, Watkins SC, Traub LM. Disabled-2 exhibits the properties of a cargo-selective endocytic clathrin adaptor. EMBO J. 2002;21:4915-26.

19. Calderwood DA, Fujioka Y, de Pereda JM, Garcia-Alvarez B, Nakamoto T, Margolis B, McGlade CJ, Liddington RC, Ginsberg MH. Integrin beta cytoplasmic domain interactions with phosphotyrosine-binding domains: a structural prototype for diversity in integrin signaling. Proc Natl Acad Sci U S A. 2003;100:2272-7.

20. Keyel PA, Mishra SK, Roth R, Heuser JE, Watkins SC, Traub LM. A single common portal for clathrin-mediated endocytosis of distinct cargo governed by cargo-selective adaptors. Mol Biol Cell. 2006;17:4300-17.

21. Morris SM, Cooper JA. Disabled-2 colocalizes with the LDLR in clathrincoated pits and interacts with AP-2. Traffic. 2001;2:111-23.

22. Zhou J, Hsieh JT. The inhibitory role of DOC-2/DAB2 in growth factor receptor-mediated signal cascade. DOC-2/DAB2-mediated inhibition of ERK phosphorylation via binding to Grb2. J Biol Chem. 2001;276:27793-8.

23. Xu XX, Yi T, Tang B, Lambeth JD. Disabled-2 (Dab2) is an SH3 domain-binding partner of Grb2. Oncogene. 1998;16:1561-9.

24. Zhou J, Scholes J, Hsieh JT. Characterization of a novel negative regulator (DOC-2/DAB2) of c-Src in normal prostatic epithelium and cancer. J Biol Chem. 2003;278:6936-41.

25. Koral K, Erkan E. PKB/Akt partners with Dab2 in albumin endocytosis. Am J Physiol Renal Physiol. 2012;302:F1013-24

26. Kowanetz K, Terzic J, Dikic I. Dab2 links CIN85 with clathrin-mediated receptor internalization. FEBS Lett. 2003;554:81-7.

27. Huang $\mathrm{CH}$, Cheng JC, Chen JC, Tseng CP. Evaluation of the role of Disabled-2 in nerve growth factor-mediated neurite outgrowth and cellular signalling. Cell Signal. 2007;19:1339-47.

28. Jiang $Y$, He X, Howe PH. Disabled-2 (Dab2) inhibits Wnt/beta-catenin signalling by binding LRP6 and promoting its internalization through clathrin. EMBO J. 2012;31:2336-49.

29. Jain $N$, Nguyen $H$, Friedline $R H$, Malhotra N, Brehm M, Koyanagi M, Bix M, Cooper JA, Chambers CA, Kang J. Cutting edge: Dab2 is a FOXP3 target gene required for regulatory T cell function. J Immunol. 2009;183:4192-6.

30. Penheiter SG, Singh RD, Repellin CE, Wilkes MC, Edens M, Howe PH, Pagano RE, Leof EB. Type II transforming growth factor-beta receptor recycling is dependent upon the clathrin adaptor protein Dab2. Mol Biol Cell. 2010;21: 4009-19.

31. Tseng CP, Huang CH, Tseng CC, Lin MH, Hsieh JT, Tseng CH. Induction of disabled-2 gene during megakaryocyte differentiation of k562 cells. Biochem Biophys Res Commun. 2001:285:129-35.

32. Tseng CP, Huang $\mathrm{CL}$, Huang $\mathrm{CH}$, Cheng JC, Stern A, Tseng CH, Chiu DT. Disabled-2 small interfering RNA modulates cellular adhesive function and MAPK activity during megakaryocytic differentiation of K562 cells. FEBS Lett. 2003;541:21-7

33. Huang CL, Cheng JC, Liao CH, Stern A, Hsieh JT, Wang CH, Hsu HL, Tseng CP. Disabled-2 is a negative regulator of integrin alpha(Ilb)beta(3)-mediated fibrinogen adhesion and cell signaling. J Biol Chem. 2004;279:42279-89.

34. Hung WS, Huang CL, Fan JT, Huang DY, Yeh CF, Cheng JC, Tseng CP. The endocytic adaptor protein Disabled-2 is required for cellular uptake of fibrinogen. Biochim Biophys Acta. 1823;2012:1778-88.

35. Huang CL, Cheng JC, Kitajima K, Nakano T, Yeh CF, Chong KY, Tseng CP. Disabled-2 is required for mesoderm differentiation of murine embryonic stem cells. J Cell Physiol. 2010;225:92-105.

36. Tseng $C P$, Chang P, Huang $C L$, Cheng JC, Chang SS. Autocrine signaling of platelet-derived growth factor regulates disabled-2 expression during megakaryocytic differentiation of K562 cells. FEBS Lett. 2005;579:4395-401.

37. Morris SM, Arden SD, Roberts RC, Kendrick-Jones J, Cooper JA, Luzio JP, Buss F. Myosin VI binds to and localises with Dab2, potentially linking receptor-mediated endocytosis and the actin cytoskeleton. Traffic. 2002;3:331-41

38. Inoue A, Sato O, Homma K, Ikebe M. DOC-2/DAB2 is the binding partner of myosin VI. Biochem Biophys Res Commun. 2002;292:300-7.
39. Hosaka K, Takeda T, lino N, Hosojima M, Sato H, Kaseda R, Yamamoto K, Kobayashi A, Gejyo F, Saito A. Megalin and nonmuscle myosin heavy chain IIA interact with the adaptor protein Disabled-2 in proximal tubule cells. Kidney Int. 2009;75:1308-15.

40. Tseng CP, Ely BD, Pong RC, Wang Z, Zhou J, Hsieh JT. The role of DOC-2/ DAB2 protein phosphorylation in the inhibition of AP-1 activity. An underlying mechanism of its tumor-suppressive function in prostate cancer. J Biol Chem. 1999;274:31981-6.

41. Olsen JV, Vermeulen M, Santamaria A, Kumar C, Miller ML, Jensen L, Gnad F, Cox J, Jensen TS, Nigg EA, et al. Quantitative phosphoproteomics reveals widespread full phosphorylation site occupancy during mitosis. Sci Signal. 2010;3:ra3.

42. He J, Xu J, Xu XX, Hall RA. Cell cycle-dependent phosphorylation of Disabled-2 by cdc2. Oncogene. 2003;22:4524-30

43. Koral K, Li H, Ganesh N, Birnbaum MJ, Hallows KR, Erkan E. Akt recruits Dab2 to albumin endocytosis in the proximal tubule. Am J Physiol Renal Physiol. 2014;307:F1380-9.

44. Rowley JW, Oler AJ, Tolley ND, Hunter BN, Low EN, Nix DA, Yost CC, Zimmerman GA, Weyrich AS. Genome-wide RNA-seq analysis of human and mouse platelet transcriptomes. Blood. 2011;18:e101-11.

45. Teckchandani A, Toida N, Goodchild J, Henderson C, Watts J, Wollscheid B, Cooper JA. Quantitative proteomics identifies a Dab2/integrin module regulating cell migration. J Cell Biol. 2009;186:99-111.

46. Cho SY, Jeon JW, Lee SH, Park SS. p67 isoform of mouse disabled 2 protein acts as a transcriptional activator during the differentiation of F9 cells. Biochem J. 2000;352(Pt 3):645-50.

47. Drahos KE, Welsh JD, Finkielstein CV, Capelluto DG. Sulfatides partition disabled-2 in response to platelet activation. PLoS One. 2009;4:e8007.

48. Welsh JD, Charonko JJ, Salmanzadeh A, Drahos KE, Shafiee H, Stremler MA, Davalos RV, Capelluto DG, Vlachos PP, Finkielstein CV. Disabled-2 modulates homotypic and heterotypic platelet interactions by binding to sulfatides. Br J Haematol. 2011;154:122-33.

49. Xiao S, Charonko JJ, Fu X, Salmanzadeh A, Davalos RV, Vlachos PP, Finkielstein CV, Capelluto DG. Structure, sulfatide binding properties, and inhibition of platelet aggregation by a disabled-2 protein-derived peptide. J Biol Chem. 2012;287:37691-702.

50. Weiss EJ, Hamilton JR, Lease KE, Coughlin SR. Protection against thrombosis in mice lacking PAR3. Blood. 2002;100:3240-4.

51. Sambrano GR, Weiss EJ, Zheng YW, Huang W, Coughlin SR. Role of thrombin signalling in platelets in haemostasis and thrombosis. Nature. 2001:413:74-8.

52. Barrangou R, Birmingham A, Wiemann S, Beijersbergen RL, Hornung V, Smith A. Advances in CRISPR-Cas9 genome engineering: lessons learned from RNA interference. Nucleic Acids Res, 2015:43:3407-19.

53. Gaj T, Gersbach CA, Barbas 3rd CF. ZFN, TALEN, and CRISPR/Cas-based methods for genome engineering. Trends Biotechnol. 2013;31:397-405.

54. Flintoft L. Animal models: mastering RNAi in mice. Nat Rev Genet. 2011;12:380.

55. Singer O, Verma IM. Applications of lentiviral vectors for shRNA delivery and transgenesis. Curr Gene Ther. 2008;8:483-8.

\section{Submit your next manuscript to BioMed Central and we will help you at every step:}

- We accept pre-submission inquiries

- Our selector tool helps you to find the most relevant journal

- We provide round the clock customer support

- Convenient online submission

- Thorough peer review

- Inclusion in PubMed and all major indexing services

- Maximum visibility for your research

Submit your manuscript at www.biomedcentral.com/submit 